\title{
The Perception Of Hindu Community In Mataram Toward Changing On Customary Marriage Behavior
}

\author{
Ida Ayu Nyoman Widia Laksmi \\ Institut Agama Hindu Negeri Gde Pudja Mataram \\ idaayulaksmi002@gmail.com
}

Abstract

\begin{tabular}{l}
\hline Keywords: \\
\hline Perception, \\
Hindu \\
Community, \\
Behavior Change, \\
Costumary \\
Marriage \\
\hline
\end{tabular}

Kata Kunci:

Persepsi, Masyarakat

Hindu,

\begin{abstract}
This research is motivated by a change in the traditional marriage system in the Hindu community in the city of Mataram. The purpose of this study was to examine the perception of the Hindu community in the city of Mataram on changes in customary marriage behavior. Methods of this research is designed in a qualitative descriptive type with a case study model. Data were collected by observation, interview, and documentation. The collected data were analyzed using qualitative analysis techniques through data grouping, data reduction, and data interpretation. The summary of the results of this study that the Hindu community's perception of changes in customary marriage behavior in the city of Mataram could be categorized into two, namely the group that agreed and the other group did not agree. The category agreed with the reasons (1) polite and more honorable; (2) fostering a more harmonious relationship between the two parties; (3) social status and wangsa (line of descent); (4) consensual; and (5) a simpler process. Groups that disagree are categorized into three, namely (1) cultural traditions and customs; (2) ethics and courtesy; and (3) the wangsa (line of descent). The perception of the Hindu community in the city of Mataram on the mepadik and selarian marriage system in terms of time, energy and cost. Based on the results of the study it was found that the public perception of the mepadik marriage system in terms of time, then the time used was less when compared to the selarian system. The implications of changing marital behavior in terms of energy, then the energy needed in the marriage process that uses the mepadik system will use less energy when compared to the selarian system. In terms of financing, the occurrence of cost efficiency in the mepadik marriage system.
\end{abstract}

\begin{tabular}{l} 
Abstrak \\
\hline Penelitian ini dilatarbelakangi oleh adanya perubahan sistem \\
perkawinan adat pada masyarakat Hindu di kota Mataram. \\
Tujuan penelitian ini adalah untuk mengkaji persepsi \\
\hline
\end{tabular}


Perubahan

Perilaku,

Perkawinan Adat masyarakat Hindu di kota Mataram terhadap perubahan perilaku perkawinan adat. Metode penelitian ini dirancang dengan tipe deskriptif kualitatif dengan model studi kasus. Pengumpulan data dilakukan dengan observasi, wawancara, dan dokumentasi. Data yang terkumpul dianalisis dengan teknik analisis kualitatif melalui pengelompokan data, reduksi data, dan interpretasi data. Kesimpulan dari hasil penelitian ini bahwa persepsi masyarakat Hindu terhadap perubahan perilaku perkawinan adat di kota Mataram dapat dikategorikan menjadi dua, yaitu kelompok setuju dan kelompok lainnya tidak setuju. Katagori setuju dengan alasan (1) sopan dan lebih terhormat; (2) pembinaan hubungan yang lebih harmonis antara kedua belah pihak; (3) status sosial dan wangsa; (4) suka sama suka; dan (5) proses lebih sederhana. Kelompok yang tidak setuju dikategorikan menjadi tiga, yaitu (1) tradisi dan adat budaya; (2) etika dan kesopanan; dan (3) wangsa. Persepsi masyarakat Hindu di kota Mataram terhadap sistem perkawinan mepadik dan selarian ditinjau dari segi waktu, tenaga dan biaya berdasarkan hasil penelitian ditemukan bahwa persepsi masyarakat pada sistem perkawinan dengan cara mepadik dilihat dari segi waktu, maka waktu yang dipergunakan lebih sedikit jika dibandingkan dengan sistem selarian. Implikasi dari perubahan perilaku perkawinan ditinjau dari segi tenaga, maka tenaga yang dibutuhkan dalam proses perkawinan yang menggunakan sistem mepadik akan menggunakan tenaga lebih sedikit jika dibandingkan dengan sistem selarian. Ditinjau dari segi pembiayaan, terjadinya efisiensi biaya pada sistem perkawinan mepadik.

\section{Introduction}

Marriage is a stage in human life. Marriage is a sacred inner and outer bond between a man and a woman to form a happy and eternal family (household) based on the One Godhead. A happy and eternal family can be achieved if the marriage is based on love, mutual trust, mutual respect between husband and wife in building a household. The purpose of marriage is to form a happy family and become a harmonious family. Hindu marriage is a sacred and sacred thing, because in the process of marriage it is carried out through a sacred process such as a holy ceremony, led by a holy person with the right timing.

The Hindu teaching, namely catur asrama is the four stages of human life. One of the stages of human life as social beings is marriage. The stage of marriage in catur asrama is grahasta (married life). "Marriage (wiwaha) is one of the tasks of human life in the grahastha stage, because if there is no marriage, no one will continue human life 
in this world and no one will carry out the dharma, a sacred task from Sang Hyang Widhi Wasa" (Jelantik, 2009:156-157).

In marriage there are two life goals to be achieved and must be completed completely, namely realizing artha and kama based on dharma. The holy book of Manawa Dharmasastra (in Jelantik, 2009: 157) says, "that the main tasks of marriage are aimed at: 1) implementing and realizing the dharma in this world, the instructions and will of Ida Sang Hyang Widi Wasa, 2) Praja, which is to produce male offspring. or women, 3) Rati, namely enjoying physically, emotionally and spiritually between two people during his life. So, marriage according to Hindu teachings is not solely for the satisfaction of lust, but marriage is a noble life obligation to produce offspring that can later be beneficial to the family, homeland and nation.

The Hindu community in West Nusa Tenggara, especially the Hindu community in the city of Mataram, has a unique tradition of marriage customs. Tradition is a human cultural heritage which, although not written, is obeyed by all levels of society who live in the area. With tradition, all aspects of society's life can give birth to a social culture that can be a role model for other regions. So, it is possible that human dignity will be taken into account in society, nation and state (Kusuma, 2003).

The tradition of marriage procedures in West Nusa Tenggara Province, especially in the unique city of Mataram, is known as "Selarian Marriage" or elopement. "Inline marriage or elopement in Manawa Dharma Sastra III verse 21 is referred to as gandharwa wiwaha which has the intention of marriage taking place consensual and continuing its implementation by running together" (Narwada, 1995:1). This marriage system has been held firmly since ancient times by the Balinese Hindu community in the city of Mataram.

In social life, everything will experience changes, all activities will refer to the mechanism of the change. Human behavior in interacting with other humans as social beings also changes. Change is generally termed a transformation. Transformation is a change in form, nature, function and so on. Likewise, the marriage behavior of the Hindu community in the city of Mataram has changed. This is in line with the expression of Wirawan (2011:141) that in Mataram city there were a number of changes in Hindus that occurred as a form of adaptation to the development of human civilization.

Marriage by selarian or elopement is no longer the only marriage system adopted by the Hindu community in the city of Mataram. Today, many people carry out marriages by way of begging or dipadik. Changes do not only occur in the marriage system, but 
there is also a shift in the selarian marriage process from the time the prospective bride is rushed to the ceremony of mepamit, both in terms of the procedures for implementation to the length of time used in the marriage process.

Today, the Balinese Hindu community in the city of Mataram recognizes two marriage systems, namely the elopement or selarian system and the mepadik system or marriage by proposing. Both of these marriage systems began to be taken into consideration by the community in choosing the marriage system to be used. The inline marriage system is no longer the only marriage system adopted and believed by the Balinese Hindu community in Mataram city, West Nusa Tenggara Province. Some people began to use the mepadik system, and some did not agree with the marriage system and still persisted in maintaining the selarian system.

Based on this description, this research focuses on two problem formulations. First, what is the perception of the Hindu community towards changes in customary marriage behavior in Mataram city? Second, what are the implications of changing marital behavior in the Hindu community of Mataram city? The general purpose of this research is to examine the perception of the Hindu community towards changes in the behavior of traditional marriages in Mataram city. The objectives of this study are twofold, namely (1) to describe the perception of Hindus on changes in the behavior of traditional marriages in the city of Mataram; (2) to identify the implications of the Hindu community of Mataram city on changes in customary marriage behavior.

\section{Method}

\section{Types of Research}

This study uses a descriptive qualitative type. Creswell (in Patilima, 2005:3) defines "a qualitative approach as an inquiry process to understand social problems or human problems, based on creating a holistic picture formed by words, reporting detailed views of informants, and arranged in a scientific setting". Meanwhile, according to Taylor and Bogdam (in Suyanto \& Sutinah, 2006:166) argues that the notion of qualitative research can be interpreted as research that produces descriptive data about spoken and written words, and observable behavior from the people being studied ".

Descriptive Research is "a method that is carried out in researching an object or a condition in a group of events in the future with the aim of making descriptive, 
descriptive, factual and accurate systematic pictures of facts, the nature of a relationship between the phenomena being investigated" (Nasir, 2003:55).

\section{Data Types and Sources}

The type of data used is qualitative data. Qualitative data is data expressed in the form of sentences, statements or descriptions sourced from informants such as: policy holders, lecturers, employees in the research area (Suprayogo and Tobroni, 2001:162).

Sources of data used in this study are primary data and secondary data. Primary data is "data that is obtained from the first source, either individually or individually, such as the results of interviews or the results of filling out questionnaires that are usually carried out by researchers" (Umar, 2004:42). Primary data were obtained from selected informants such as: religious leaders, community leaders, pinandita and other informants who were considered to know about the research area, about their perceptions of changes in customary marriage behavior that occurred in the Hindu community in Mataram city, as well as their perceptions of the relationship as a result. the change in marriage when viewed in terms of time and cost. This data is raw data that still needs to be processed. While secondary data is data that is informative, obtained from relevant documents and has something to do with the research carried out.

\section{Data Collection Technique}

To obtain the data, information and information needed in this study, several data collection techniques were used, namely observation, interviews, and literature and documentation studies. First, observation, conducting observations and research directly to the research site to complement and support primary data. In this study, observations were made about the behavior of traditional marriages in the Hindu community in the city of Mataram.

Second, the interview technique is a way to get deeper data through interviews conducted by researchers to all informants. The interview used is an in-depth interview, where in-depth interviews are conversations between researchers and informants, with certain goals. The objectives to be achieved in in-depth interviews are to obtain constructions that occur about people, events, organizational activities, feelings, motivations, and knowledge of a person (Arifin, 1994: 65). According to Nasution (1998) that interview techniques like this are mainly carried out on the opinions, perceptions, 
feelings, knowledge, and experiences as well as sensing one's informants. This interview was conducted on religious leaders, traditional leaders, pinandita, banjar leaders and other informants who were considered to know about the research area located in Mataram city.

Third, the study of literature and documentation is carried out by studying and recording reading materials, papers, journals, documents and reports, as well as other materials related to research variables. The data obtained using this technique is data relating to the general description of the research location, namely an overview of the city of Mataram seen from geographical conditions, government and administration, ethnicity and population, which was obtained from the Public Relations of the Mataram Mayor's Office and the number of residents obtained data from Mataram City Central Bureau of Statistics and Mataram City Ministry of Religion Affair Office.

\section{Data Analysis Techniques}

The data analysis technique used in this research is descriptive qualitative analysis. The procedure used in the analysis includes the stages of classification, interpretation, and drawing conclusions. Research is conducted with one main objective, namely to answer research questions to reveal certain social or natural phenomena. To achieve this main goal, researchers formulate hypotheses, collect data, make analysis and interpretation (Singarimbun, 1995). In scientific research all the symptoms that will be revealed in depth truth and the results are commonly called data. The data collected must be valid data. The validity of the data can be improved by data collection techniques and the quality of data collection is quite valid. The data collection techniques used in this study were in the form of direct observation, interviews, documentation and literature. The data obtained is still raw data. The raw data that has been collected by the researcher will be of no use if it is not analyzed.

The raw data that has been collected needs to be sorted into groups, categorised, analyzed in such a way that the data has meaning to answer the research problem. Manipulating raw data means changing the raw data from its initial form into a form that can easily show the relationships between phenomena. several levels of activities need to be carried out, including checking the raw data once again, making it in the form of a useful table (Nazir, 1999). 


\section{Results and Discussion}

\section{Hindu Community Perceptions of Changes in Customary Marriage Behavior}

Changes in customary marriages that have occurred in the city of Mataram have led to polarization of opinion, namely two different opinions. The first group are those who agree with the change in marital behavior and the second group are those who do not agree with the change in marital behavior. In this regard, so far, the opinion of the informants included in the agree category is the statement of Mangku Susila (an informant) stated that the mepadik method was very good because the women felt valued and respected by the men. Ida Bagus Juni Heriawan (an informant) stated that women felt respected. This opinion is also supported by Ni Putu Sudewi Budhawati (an informant) who stated that apart from being respected, if in the future unpleasant things happen, they can be resolved in an honorable way. This opinion was also corroborated by Desak Ayu Laksmini Dewi (an informant). Ni Made Devi (an informant) stated that marriage with mepadik would give the impression of being more polite. The same thing was also conveyed by I Gusti Ayu Aditi (an informant) who also expressed his opinion about mepadik on the grounds that women would be more respected than using the inline marriage system.

The opinion that states that mepadik marriage is a marriage system that they agree with on the grounds that it is more honorable than using the selarian marriage system is Sayu Kade Jelantik (an informant) who stated that mepadik marriage, apart from being more polite, women also feel more respected. The opinion groups that agree from several informants on the changes in marriage that occur today in the community in the city of Mataram as described above are based on the group for reasons of decency and honor. The reason for politeness is because this method uses good ethics with the man introducing himself first to the woman's family. The ethic shown is to express a desire first or show an attitude of apologizing to the woman's family. This method is considered by the informant as a polite attitude. If you don't excuse yourself before taking your prospective bride, you are considered unethical and you are polite. This action will lead to a lack of respect for the prospective bride's family. This is the reason the informant above agrees with the mepadik marriage system, so he agrees with the change in customary marriage from selarian to mepadik marriage. The opinion in the category agrees for the second group of reasons as conveyed by Mangku Susila (an informant) who also agrees that there is a change in marriage behavior in line with mepadik today on the 
grounds that the mepadik system will create a good relationship from the beginning to the end of the marriage process. This opinion was also confirmed by Ida Made Prayatna (an informant) who stated that with mepadik, the relationship between the two parties is harmonious because they already know each other. Meanwhile, there is no agreement between the two parties which will cause the relationship between the two families to be not harmonious. This opinion was also confirmed by Ida Bagus Heri Juniawan (an informant) who gave the reason that this system would further strengthen brotherhood with the families of both parties. The reason for creating a good relationship with the mepadik system was also expressed by Gusti Ayu Aditi (an informant) who revealed that by creating better relations with both families from the start.

In line with the above phenomenon, Ida Nyoman Ariana (an informant) said that the mepadik marriage system is better than the selarian marriage system because the mepadik system can build better relationships with both families early and all families are happy from the start of the marriage process. Ni Made Devi (an informant) also stated that with mepadik, it can further strengthen the relationship between the two families of the prospective bride and groom. This opinion was also confirmed by I Nyoman Bagiartha (an informant) who stated that mepadik can maintain good relations.

From the statements of several informants related to their perception of the changes in the marriage system that occur today in the Hindu community in the city of Mataram, they agree with the change. Their reasons for this change are grouped into the second group of reasons, namely that mepadik can create a better and closer relationship between the two families of the prospective bride and groom. This better relationship will create a harmonious relationship from the beginning of the marriage process to the end. There is no tension between the two families of the prospective bride and groom as would be created if using the inline marriage system. Both families are happy in welcoming the marriage that is carried out. The reason is in accordance with the marriage procedure called Mapekardi, this procedure is carried out on the basis of the agreement of both families with a full sense of kinship.

The opinion of informants on marriages that occur today in Hindu communities in the city of Mataram is next included in the third group as conveyed by Ida Bagus Sumiana, who stated that by using the mepadik method, the two families of the prospective bride and groom already know the social status of each prospective bride's family. Families also know beforehand about the bobot, bebet and bibit of each. Ida Bagus 
Sumiana also stated that he agreed to mepadik marriage, if it was carried out by a family who came from the same wangsa (line of descendant).

Judging from the reasons for social status and from the family clan of the bride and groom, the same opinion was also expressed by Ida Wayan Djelantik (an informant) who stated that if the families of both parties are from the same dynasty, it is better to use the mepadik system of marriage. Although not from the same family, the bobot, bebet, and bibit of the bride and groom were known earlier. But if you come from a family that is not of the same wangsa, the female clan is higher than the male, then you should use the selarian system. Based on the same opinion about the wangsa as the reason for agreeing with the mepadik marriage system, it was also stated by the informant Desak Ayu Laksmini Dewi (an informant) who had carried out a marriage with the mepadik system with a husband who came from the same wangsa. This reason was also approved by Ida Nyoman Ariana who stated that she agreed with the mepadik system if the two prospective brides were from the same wangsa.

Based on the informant's statement above, the informant agreed with the mepadik system of marriage by including their reasons in the third group, namely regarding the social status of the two families, such as bobot, bebet and bibit which they feel are good. In addition, social status is seen from the two families of the prospective bride and groom. If you come from the same wangsa, then you should use the mepadik marriage system, but if you come from a different dynasty, especially if the women are from a higher dynasty, then you should use the selarian system. The wangsa system in the Hindu community in the city of Mataram is still very strongly attached to the social life of the Hindu community until now.

The next opinion regarding changes in customary marriage behavior that occurs in Hindu society in Mataram city today, included in the fourth group, was put forward by Ida Made Prayatna (an informant) who expressed his opinion that the change from selarian to mepadik was on the grounds that an agreement had been reached between the two parties in family. So that, both families already know the relationship of the two prospective brides and agree to their relationship to the point of marriage. This opinion is also the same as the opinion expressed by Desak Ayu Laksmini Dewi (an informant) who stated that in implementing the mepadik marriage system based on the two, they already had the same feeling, namely mutual liking and had a commitment that they would implement the marriage system with mepadik. This opinion was also expressed by 
Nengah Rahta (an informant) that the mepadik marriage system is now widely practiced because both parties mutually agree to carry out the marriage.

The opinion above states that mepadik marriage is carried out on the grounds that both parties already know each other's relationship and both parties are consensual and both families also support the relationship of the bride and groom to the marriage stage. This reason causes the mepadik system to be used by the Hindu community in the city of Mataram today. This reason is in accordance with the level of marriage that has been stated in the holy book of Manawa Dharmasastra, namely a form of marriage called arsha wiwaha. The arsha wiwaha is a form of marriage based on consensual feelings between the two prospective brides.

The grouping of informants' answers in the fourth group was stated in the answer of the informant Ni Made Devi Noviyanti (an informant) who stated that the mepadik system takes a long time, but with the mepadik system, it saves more time. A similar opinion was also conveyed by I Gde Warga (an informant) who stated that with the mepadik system the process was not too long and not complicated. The simple and uncomplicated process of mepadik marriage was also emphasized by Ni Luh Windari (an informant) who stated that the mepadik marriage process was simpler than selarian or elopement. This was also supported by Wayan Arthabawa (an informant) who stated that mepadik doesn't take long, doesn't need to take days.

Starting from the opinion of the informants above, the opinion about changes in customary marriage behavior in the people of Mataram city today, they agree with the reasons that fall into the fourth group category, namely the reason that the mepadik process does not take long with a simple and uncomplicated process.

The second group, namely those who do not agree with the behavior of mepadik marriage, express a number of arguments which are basically used to strengthen their disagreement. These opinions, as expressed by Ida Made Singarsa (an informant) who expressed his disagreement with the mepadik marriage system. The opinion of Ida Made Singarse (an informant) on selarian is used because this system has become a tradition of the people of Mataram city and its surroundings for generations. So, this tradition needs to be maintained. This statement was also approved by I Wayan Sudiana (an informant) who emphasized his disapproval of mepadik marriage, because it is not in accordance with the customs that have been believed by the Hindu community in Mataram city for generations. This informant wants the cultural customs that have been received from their 
ancestors from generation to generation to be preserved. This running system is still firmly adhered to by this informant and all residents in the neighborhood where he lives.

Another opinion that is in line with the opinion of the informant above was also conveyed by Made Putra (an informant) on the grounds that elopement has been a tradition for a long time. This was also confirmed by Ni Made Dewi Desi Antari Putri (an informant) who stated that the traditional marriage customs of Lombok were selarian.

Based on the statements submitted by the informants as outlined above, the opinion about the behavioral changes that are happening today in the Hindu community in the city of Mataram, can be categorized in the element of disagree. The reasons for not agreeing with the change in the behavior of traditional marriages in the Hindu community in the city of Mataram today, from selarian to mepadik marriages, are grouped on the reasons for maintaining the existing cultural traditions that have been applied for generations.

The second group regarding the reasons for not agreeing with the mepadik marriage was conveyed by the informants as described below. Ida Made Singarsa (an informant) who stated that the mepadik system was considered insulting to women because they would ask someone else's girl. This strengthens the reason why this informant does not agree with marriage with the mepadik system. Ni Made Desi Antari Putri (an informant) stated that by asking for a mepadik marriage process, the man was considered insulting the woman because asking someone else's daughter after she grew up was considered disrespectful.

Informants' statements as above, are included in the second group of reasons, namely with the existence of mepadik marriages, they do not agree with the assumption that the implementation will take place by putting aside ethics so that women are offended by men who apply or ask for children. This offense results in feelings of humiliation. This is the reason why the informants do not agree with the change in the behavior of traditional marriages in the Hindu community in the city of Mataram recently from selarian marriages to mepadik marriages.

The next reason for the disapproval of informants with mepadik marriage is because of wangsa differences. This was revealed in a statement by Ida Bagus Sumiana (an informant) who stated that if the caste of the women was higher than that of the men, the selarian system should be used. This statement was also emphasized by Ida Wayan Djelantik (an informant) with the statement that if the bride and groom come from 
different wangsa, in this case the wangsa of the prospective bride is higher, then the selarian system must be used. The same thing was also expressed by Ida Nyoman Ariana and I Nyoman Dedi Saputra (both of whom were informants).

The reasons mentioned above can be grouped into a third group with a statement that they do not agree with the existence of a mepadik system marriage based on the caste of the two parties who are not the same. Not the same here is meant if the caste of the male side is lower than the female side.

Based on the statements of the informants above, it can be categorized into two categories, namely agreeing with changes in customary marriage behavior in the Hindu community in Mataram city and the second category is not agreeing with changes in marital behavior. The reasons for agreeing can be grouped into five groups, namely polite and more respectable, fostering a more harmonious relationship between the two parties, social status and wangsa, consensual and simpler processes. Meanwhile, the disagree category is grouped into three groups, namely cultural traditions and customs, ethics and courtesy, and wangsa.

\section{Implications of Changes in Customary Marriage Behavior in Hindu Society}

The mepadik and selarian systems marriages in Mataram city in terms of time, energy and cost are described in part. Starting in terms of time, Mangku Made Susila (an informant) stated that in terms of time, mepadik marriages can be shortened depending on the agreement of both parties so that it can be time efficient. The same opinion was also given by I Wayan Wibawa (an informant) who stated that in terms of time it was lighter than the selarian system. This is because in the marriage process, everything is shared by both parties. Ida Bagus Sumiana (an informant) stated that in terms of time, mepadik marriages require a shorter and simpler time when compared to selarian marriages.

A similar opinion was also conveyed by Ida Made Singarsa (an informant) who stated that the process of selarian marriage takes longer than the mepadik process. Ida Made Prayatna (an informant) who said that mepadik marriage takes a shorter time and does not take too long, because the process is simpler. In the roaming process, it takes longer with a more complicated process. The same thing was conveyed by Ida Bagus Heri Juniawan and Ni Putu Sudewi Budhawati (both of whom were informants) stating the 
same thing, namely with the mepadik marriage system the implementation time is shorter when compared to the selarian system.

The same opinion was conveyed by Gusti Ayu Aditi (an informant) who stated that the mepadik method is simpler and less complicated so that it takes less time. Ida Wayan Djelantik (an informant) stated that with mepadik marriage, the process required is less than the selarian method which can take months. This opinion was also reaffirmed by Desak Ayu Laksmini Dewi (an informant) who stated that less time was used because the process was not difficult. The same opinion was also conveyed by I Wayan Sudiana. Ida Nyoman Ariana (an informant) stated that elopement takes a long time, up to months, but mepadik marriages do not take a long time, in short, within one month, the marriage process has been completed.

In line with the above, Nengah Rahta (an informant) expressed his opinion that the selarian marriage process does take a long time and can sometimes nearly other activities, while the mepadik system in its implementation is faster than selarian. The same opinion was conveyed by I Nyoman Dedi Saputra, Made Putra, Ketut Sodiartha, Ni Made Devi (all four of whom were informants) who stated that the time was shorter without being complicated and could be completed in one day. Time saving by using the mepadik system was also conveyed by a number of informants, such as Sayu Kadek Jelantik, Ni Made Devi Novitayanti, I Gde Warga, Ni Luh Windari, I Wayan Widhiartha, and Wayan Arhabawa.

From the opinion of the informants above, all of them stated that marriage with the mepadik system, when viewed from the point of view of the time used during the marriage process, did not require a long time. There were those who expressed their opinion that the process would take a maximum of one month to complete. Some even argue that the mepadik system only takes one day. Besides the time required is not long, the process carried out is also simple and not complicated.

Meanwhile, the informants also argued that the selarian system takes longer in the marriage process than the mepadik system. It can even take months. From the opinion of the informants above, it can be concluded that the mepadik marriage system which is carried out in the Hindu community in Mataram city today, in terms of time, is less than the selarian system, where the selarian system is a system that has been used since ancient times. from generation to generation to the present day. 
If viewed from the aspect of energy, the statement obtained from the informant is as follows. Mangku Made Susila (an informant) stated that the energy used when the mepadik process was carried out was not much, so it was more energy efficient when compared to the selarian system. The same opinion was also conveyed by a number of informants, such as I Wayan Wibawa, Ida Bagus Sumiana, Ida Made Singarsa, Ida Made Prayatna who stated that less energy was used when compared to the selarian process of marriage.

The same opinion was conveyed by Ida Bagus Heri Juniawan (an informant) who stated that marriage with the mepadik system uses less energy than selarian. This statement was also conveyed by several informants, such as Ni Putu Sudewi Budhawati, Gusti Ayu Aditi, Ida Wayn Djelantik, Desak Ayu Laksmini Dewi, and I Wayan Sudiana. Ida Nyoman Ariana (an informant) stated that elopement requires a lot of energy, while the mepadik marriage system requires less energy because both parties help each other in completing the marriage process. This opinion was also confirmed by I Nyoman Dedi Saputra (an informant) who stated that the mepadik process did not use much energy. A similar opinion was also conveyed by several informants, such as Ketut Sodiartha, Sayu Kadek Jelantik. Wayan Arthabawa expressed the opinion that the selarian system is energy-consuming because it is needed for long trips. Meanwhile, a different reason from the opinion of the previous informant was presented by Nengah Rahta (an informant) said that mepadik marriages require more energy than marriages with the selarian system.

Based on the informant's statement about the energy needed in the marriage process using the selarian or mepadik system, it can be concluded that marriages using the mepadik system will use less energy when compared to the selarian system. This is because the time used by the mepadik system is less, so it has implications for the energy used. The less time it takes, the less energy it uses. Marriage with a contrarian system takes a long time, so the energy expended will be even more. So, the energy used in the selarian system is more than the mepadic system. There is energy efficiency in the medical system.

If viewed in terms of the costs incurred in the marriage process carried out in the Hindu community in the city of Mataram today, it can be seen from the opinion of the informant as follows. Mangku Made Susila (an informant) stated that the mepadik system requires less money from the male side, because the financing can be jointly handled by both parties. The same statement was also conveyed by I Wayan Wibawa (an informant) 
who stated that from the male side, the expenditure during the mepadik marriage process was less than in the selarian system because it was jointly handled by both parties. A similar opinion was also conveyed by Ida Bagus Heri Juniawan (an informant) who stated that in terms of financing, the mepadik system would be cheaper, because it was jointly borne by both the families of the bride and groom. This opinion was also conveyed by $\mathrm{Ni}$ Putu Sudewi Budhawati (an informant) who stated that mepadik marriages were cheaper than sideline marriages. This is because the financing in the marriage process can be handled jointly from both sides of the prospective bride's family. The same statement was also conveyed by Gusti Ayu Aditi (an informant) who stated that the financing of the mepadik system was more economical. The same statement was conveyed by Desak Ayu Laksmini Dewi (an informant) who stated that, regarding the financing of the mepadik system, there was cost savings from the men because the financing of the wedding ceremony could be jointly handled by both parties. Ida Made Prayatna (an informant) stated that the financing for the mepadik system is less than the men, because the costs are shared between the two parties. Meanwhile, most of the costs for the selarian system are borne by the men, because all costs are borne by the men.

Another opinion was given by the informant regarding the costs incurred in the marriage process, either using the selarian system or using the mepadik system. Ida Bagus Sumiana (an informant) expressed her opinion about the same costs incurred in the process of selarian as well as mepadik. The same opinion was also conveyed by Ida Made Singarsa (an informant) who stated that the costs incurred were the same for the two marriage systems. Informants I Wayan Sudiana and Ida Nyoman Ariana (informants) also stated that the costs incurred were the same between the two marriage systems mentioned above. The last same statement was made by Made Putra.

Ida Wayan Djelantik (an informant) gave a different opinion from the opinion of the previous informant, who stated that in the mepadik system, men spend more money. This is because all costs incurred by both parties in the marriage process are borne by the men. Meanwhile, the financing issued by women is the same whether using the selarian system or the mepadik system. Based on the informant's statement on the perception of the costs incurred in the marriage process held in the Hindu community in Mataram city, both with the selarianan and mepadik systems, they can be grouped into three groups. The first group stated that the cost efficiency incurred by the community by using the mepadik system. If using the selarian system, the costs to be incurred will be greater than 
the mepadik system. Then the second group stated that the expenditure was the same between the mepadik marriage system and the selarian marriage system. The third group presented by one informant stated that the mepadik system marriage costs more when compared to the selarian system, when viewed from the male side. But, if viewed from the woman's side, the costs incurred are the same between the two marriage systems.

Based on the discussion presented above, by looking at the number of informants who expressed opinions in each of the groups above, the statements submitted by the informants are in the first group. So, it can be concluded that the perception of the Hindu community in the city of Mataram on the financing spent on the selarianan and mepadik marriage systems is the cost efficiency of the mepadik marriage system.

\section{Conclusion}

The Hindu community perceptions of changes in customary marriage behavior in Mataram city can be categorized into two categories, namely agree and disagree. The categories agree with the reasons, namely (1) polite and more respectable; (2) fostering a more harmonious relationship between the two parties; (3) social status and clan; (4) consensual; and (5) the process is simpler. Meanwhile, the category of disagreement is grouped into three groups of reasons, namely (1) cultural traditions and customs;(2) second, ethics and courtesy; and (3) wangsa.

The implications of changing the behavior of traditional marriages to the Hindu community of Mataram city involve time, effort, and cost. The behavior of mepadik and Selarian marriages, when viewed in terms of time, energy and costs, it can be concluded that, the public perception of the mepadik marriage system carried out in Hindu communities in Mataram city today is seen in terms of time, then the time used is less when compared with the selarian system, where the selarian system is a system that has been used since antiquity from generation to generation until now. People's perceptions of changes in marital behavior in Hindu society in Mataram city today when viewed in terms of energy, then the energy needed in the marriage process using the mepadik system will use less energy when compared to the selarian system. In terms of costs incurred, there is a cost efficiency in the mepadik marriage system. So, there is an efficiency of time, energy, and cost on the behavior of customary marriages in the Hindu community in the city of Mataram by using the mepadik system of marriage. 


\section{References}

Agung, G. (1999). Metodologi Penelitian Pendidikan. Singaraja : STKIP Negeri

Anonim. (2013). Persepsi. Id.m.wikipedia.org. diakses tanggal 18 Agustus 2013

Anonim. (2013). Masyarakat. Id.m.wikipedia.org. diakses tanggal 18 Agustus 2013

Anonim. (2012). Pengertian dan Definisi Masyarakat Menurut Para Ahli. www.carapedia.com. Diakses tanggal 10 Agustus 2013

Anonim. (2005). Undang-Undang Perkawinan, Himpunan Peratutan Perundangundangan. Bandung : Fokusmedia

Arikunto, Suharsini. (2002). Prosedur Penelitian Suatu Pendekatan Praktek. Jakarta: Rineka Cipta

Asmin. (1986). Status Perkawinan Antar Agama. Jakarta : PT. Dian Rakyat

Azwar, Saifudin. (2010). Sikap Manusia Teori dan Pengukurannya. Yogyakarta: Pustaka Pelajar

Bangli, Ida Bagus. (2005). Mutiara Dalam Budaya Hindu Bali, Pedoman Guide. Surabaya : Paramita

Dewasastra. (2012). Konsep dan Pengertian Perilaku. Dewasastra.worpress.com. diakses tanggal 25 Juli 2013

Efelina. (2012). Pengertian Persepsi-Definisi Persepsi. Blog.ub.ac.id diakses tanggal 18 Agustus 2013

Goa, Hillon. (2009). Apakah Transformasi Itu?. Transformasi-org.blogspot.com. diakses tanggal 8 Agustus 2013

Gulo, W. (2004). Metode Penelitian. Jakarta : PT. Gramedia Widiaswara Perkasa

Intaran, I Made. (2003). Kawin Selarian Sebagai Bentuk Perkawinan Umat Hindu Suku Bali di Kelurahan Cakrenegara Timur Kecamatan Cakrenegara Kota Mataram. Skripsi pada Sekolah Tinggi Agama Hindu Negeri Gde Pudja Mataram

Jaman, I Gde. (1998). Membina Keluarga Sejahtera, Grha Jagadhita. Surabaya : Paramita

Jelantik, Oka, Gde Ida Pedanda. (2009). Sanantana Hindu Dharma. Denpasar : Widya Dharma

Khairuliksan. (2012). Konsep Persepsi. Khairuliksan.blogspot.com, akses tanggal 15 Juli 2013

Kusuma. Artha. (2003). Mempertimbangkan Tradisi. Mataram : Yayasan Dewi Saraswati Mataram 
Laksmi, Widia, Ida Ayu Nyoman. (2010). Transformasi Perilaku Perkawinan Adat Suku Bali Di Kota Mataram. Hasil Penelitian. STAHN Gde Pudja Mataram. Mataram Majid. (2008). Pengertian Masyarakat. www.wordpress.com diakses tanggal 8 Agustus 2013

Margono. (1996). Metode Penelitian Pendidikan. Jakarta : Rineka Cipta

May, Abdurrachman. (2006). Persepsi dan Sikap Tokoh Agama terhadap Esistensi Pariwisata Lombok, Tesis. Denpasar: fakultas Sastra Unud

Moeliono, dkk. (1996). Kamus Besar Bahasa Indonesia. Jakarta: Balai Pustaka

Nasir, Mohamad Fikal. (2013). 10 Definisi Perilaku Menurut Para Ahli. Thefriedkerz.blogspot.com. diakses tanggal 2 Agustus 2013

Nasir, Moh. (2003). Metode Penelitian. Jakarta : Ghalia Indonesia

Narwada, I.K.T. (1995). Indik Rangkat Suku Bali Lombok. Mataram : Manik Kembar

Patilima, Hamid. (2005). Metode Penelitian Kualitatif. Bandung : CV. Alvabeta

Pudja, I Gde, dan Sudartha, Tjokorda Rai. (2002). Menawa Dharma Sastra. Jakarta : CV. Felita Nursatama Lestari

Raka, Mas Gde. (2002). Perkawinan Yang Ideal. Surabaya : Paramita

Sandrajaya. (2011). Pengertian Perilaku. Id.shvoong.com. diakses tanggal 25 Juli 2013

Sarwono, Sarlito Wirawan. (2003). Teori-teori Psikologi Sosial. Jakarta : PT Raja Grafindo Persada

Septiyanti, Dwi. (2013). Teori Organisasi Umum dan Perubahan. http://sartikaraharjo.blogspot.com diakses tanggal 8 Agustus 2013

Sumarda, Cakra, I Gde. (2010). Pelaksanaan Perkawinan Dalam Hukum Adat Bali Tinjauan Undang-Undang Nomor 1 Tahun 1974 Perspektif Pluralisme Hukum Di Kota Mataram. Tesis pada Program Pasca Sarjana Jurusan Hukum Universitas Mataram

Suprayogi dan Tobroni. (2001). Metode Penelitian Sosial Agama. Bandung : PT. Remaja Rosdakarya

Suyanto, Bagong \& Sutinah. (2006). Metode Penelitian Sosial, Berbagai Alternatif Pendekatan. Jakarta : Kencana

Titib, I M. (1997). Perkawinan dan Kehidupan Keluarga, Menurut Kitab Suci Veda. Surabaya : Paramita

Ucha. (2013). Pengertian Masyarakat. 9triliun.com diakses pada tanggal 10 Agustus 2013 
Umar, H. (2004). Riset Sumber Daya Manusia. Cetakan Ke Enam. Jakarta: PT. Gramedia Pustaka Utama

Wirawan, I W. A. (2014). Reproduction Identity Mechanism at Pasek Community in Mataram City, West Nusa Tenggara. Humaniora. Vol. 23. No.2. pp.140-149. https://doi.org/10.22146/jh.1017 